\title{
NOTES
}

\section{TAXATION OF SUPPORT PAYMENTS TO A DIVORCED SPOUSE UNDER PRIVATE AGREEMENT*}

Divorce or legal separation usually requires the husband to make payments for the support of the wife. ${ }^{1}$ Payments may be in the form of court decreed alimony or contractual obligations under a private agreement between the parties. $^{2}$ Before 1942 such payments were not taxed to the wife. ${ }^{3}$ And the husband could not deduct them, ${ }^{4}$ although in some states judicious use of the trust device actually permitted tax results similar to a deduction. But this treatment seemed inequitable: wives received tax-free windfalls; husbands could not deduct a burdensome expense ${ }^{6}$ and variations in state law allowed only some husbands to manipulate the trust device for tax benefits.

To achieve fairness ${ }^{8}$ and tax uniformity, ${ }^{9}$ Congress in 1942 added two sections to the Internal Revenue Code. ${ }^{10}$ Section $22(k)$ now requires the wife to include in her gross income periodic payments, received subsequent

*Lerner v. Commissioner, 195 F.2d 296 (2d Cir. 1952) ; Smith v. Commissioner, 192 F.2d 841 (1st Cir. 1951).

1. 2 Vernier, American Fanily Laws 259 et seq. (1931).

2. For advantages of making an agreement rather than letting the court decree allmony, see Miller, Income and Divorce, 28 TAxEs 1233, 1234 (1950); Gruneberg, The Taxability of Alinony Payments Under Divorce or Separation Agreements, 17 U. KAN. City L. Rev. 52, 61 (1948).

3. Gould v. Gould, 245 U.S. 151 (1917) (alimony); Jane T. Coates, 3 B.T.A. 429 (1926) (payments made by private agreement). The tax statutes did not deal specifically with the treatment of alimony.

4. See Gould v. Gould, 245 U.S. 151, 154 (1917). See also Hearings before Committee on Way's and Means on H.R. 7378, 77th Cong., 2d Sess. 92 (1942).

5. Pearce v. Commissioner, 315 U.S. 543 (1942); Helvering v. Fuller, 310 U.S. 69 (1940). For a detailed discussion see Gornick, Alimony and the Income Tax, 29 ConNEL. L.Q. 28, 29-33 (1943).

6. See Hearings, supra note 4 , at 92.

7. SEn. Rep. No. 1631, 77th Cong., $2 d$ Sess. 83 (1942). See also Gornick, supra note 5 , at 34,35 .

8. According to the House report, $\S 22(\mathrm{k})$ was added ". . . in order to provide . . . a new income tax treatment for payments in the nature of or in lieu of alimony or an allowance for support as between divorced or legally separated spouses. These amendments are intended to treat such payments as income to the spouse actually receiving or actually entitled to receive them and to relieve the other spouse from the tax burden upon whatever the amount of such payments is under present law includible in his gross income." H.R. Rep. No. 2333, 77th Cong., 2d Sess. 71 (1942).

9. See Sen. Rep. No. 1631, 77th Cong., 2d Sess. 83 (1942).

10. INT. REv. CODE $\$ \S 22(k), 23(\mathrm{u})$. 
to a divorce or separation decree," "in discharge of . . . a legal obligation which, because of the marital ... relationship, is imposed upon or incurred by [the] husband 12 under such decree or under a written instrument incident to such divorce or separation. ..."13 Section 23 (u) allows the husband to deduct payments taxed to the wife under $22(k) .^{13}$

Alimony is clearly taxable to the wife and deductible by the husband under the statute. But payments made under private agreements encounter difficulty

11. A court order to make payments set by private agreement is not a decree within the meaning of the statute. Terrell v. Commissioner, 179 F.2d 833 (7th Cir.), ccrt. dcxicd, 340 U.S. 822 (1950). But a foreign decree is sufficient, even though the state in which the parties are domiciled does not recognize the legality of the foreign divorce. G.C.M. 25250, 1947-2 Cuns. Bulz. 32; Feinberg v. Commissioner, 4 P-H 1952 Fm. TAx SEnv. โ1 72,573 (3d Cir. 1952).

Payments under an informal separation, however, are under no circumstances tased to the wife, even when the religious beliefs of the parties prevent them from obtaining a decree. Charles L. Brown, 7 T.C. 715 (1946); Max D. Melville, 8 T.C.M1. 934 (1949). Such a policy was adopted to prevent tax evasion effected by splitting income under a bogus separation. See Smith v. Commissioner, 168 F.2d 446, 448 (2d Cir. 1948). But all married couples can now split income under the Code. INr. Rev. Cone \$12(d). And when an antagonistic wife refuses to sign the necessary joint return, her estranged husband is taxed more heavily than a husband who can split income. Taxing the wife for payments received under informal separation would encourage the wife to sign the return and would also reduce the husband's burden if she refused. See 47 MIrce. L. REv. 726 (1949).

12. For purposes of the alimony tax, the terms "husband" and "wife" are interchangeable. INT. REv. CoDE $\$ 3797$ (a) (17). But unlike the husband, the wife has no common law obligation to support. And in only nine states do statutes provide for awarding the husband alimony. Insixors Cone c. 40, 19 (Smith-Hurd, 1934); Iowa Cone $\$ 598.14$ (1949) ; MAass. Laws c. 20\$, §34 (1933) ; N. D. Rev. CODE $\$ 14-0524$ (1943); N. H. Rer. Stat. C. 339, $\$ 19$ (1942); Ohio Genkeral Code $\$ 8003-17$ (Page, Supp. 1951); OrLa. Stat. tit. 12, §1278 (1938); Ore CoMrp. Laws \$9-914(3) (1940); Wask. Rew. Star. $\$ 989$ (Remington, 1932).

Payments made for the support of minor children are not taxed to the wife if specifically set apart by the marital settlement. INT. REv. CONE $\$ 22(\mathrm{k})$; U.S. Treas. Reg. 111, $\$ 29.22(\mathrm{k})-1$ (d) (1948) ; Dora H. Moitoret, 7 T.C. 640 (1946). But ef. Robert K. MIcBerty, 16 T.C. 968 (1951). For general discussion see 1 P-H 1952 FED. TAx. SExv. II 7863 (1952).

13. INT. REv. CODE $\S 22(\mathrm{k})$. For general discussion of the statutory requirements, see 1 Miertens, Law of Federal Incone Taxation (Supp. 1951) 105-125; Gornicl; Alimony and the Income Tax, 29 CorNent L.Q. 28 (1943); Gregory, Tax Consequenecs of Marriage and Divorce, 3 ARK. L. REv. 292 (1949); Gruneberg, The Taxability of Alimony Paynents under Divorce or Separation Agreemerts, 17 U. KAs. CITY L Rev. 52 (1948); Howard, Divorce and Taxes, 8 Ala. LAwyER 33S (1947); Kramer, Alimory ard the Tax Law, 26 TAxes 1105 (1948); Lasser, The Tax Situations on Alintony Payments, $88 \mathrm{~J}$. Accountancy 396 (1949); Miller, Income and Divorce, 28 TAxes 1233 (1950); Rudick, Marriage, Divorce, and Taxes, 2 TAx L. Rev. 123 (1947).

14. INT. Rev. CODE $\$ 23(u)$.

Other sections of the Code dealing with alimony are $\$ 171$ (alimony trust payments taxed to wife), $\$ 162$ (b) (alimony payments deductible by trust or estate), $\$ \$ 12(\mathrm{~b})$ (estate tax), and $\$ 1002$ (gift tax). See also Vonderheit, Income-Tax asd Gift-Tax Aspects of Dicorce, 31 ORE. L. Rev. 1 (1951). 
in meeting two of the statutory requirements : that there be a "legal obligntion"; and that the instrument be "incident to" divorce. 15 Although in the cases these tests overlap, they are doctrinally distinct and their separation simplifies analysis.

The broad "legal obligation" language of the statute would seem to require nothing more than a binding contractual agreement. ${ }^{10}$ But courts, interpreting Congress' intent, held that the obligation to pay must be undertaken while there is a "legal obligation to support." 17 Such a requirement was easily fulfilled by agreements made prior to divorce because a husband always has an obligation to support his wife during marriage. ${ }^{18}$ On the other hand, since a divorce decree which neither awards alimony nor incorporates an agreement will almost always terminate the obligation to support, ${ }^{10}$ agreements first conceived after the decree clearly fail to meet the requirement.

But the "legal obligation to support" rationale troubled courts confronted with post-divorce revisions of agreements originally executed prior to the decree. Since divorce usually terminates the general obligation to support, ${ }^{20}$ only a court decree can maintain such an obligation after divorce. Thus in Commissioner $v$. Walsh, ${ }^{21}$ where the original agreement was not incorporated in the divorce decree, the entire amount paid under a revisionary contract was held not taxable to the wife because the payments did not begin when the husband had a legal obligation to support. ${ }^{22}$ And in Commissioner $v$.

15. As used throughout this note, "divorce" includes "legal separation."

16. The statute embraces ". . . a legal obligation which, because of the marital . . . relationship, is . . incurred by such husband . . . under a written instrument. . . ." INT. REv. CoDE $\S 22(k)$. (Emphasis added).

17. The Senate report accompanying the Act reads: "This section $[22(k)]$ applics only where the legal obligation being discharged arises out of the marital ... relationship it recognition of the general obligation to support. . . " SEN. REP. No. 1631, 77th Cong., 2d Sess. 84 (1942). (Emphasis added). For cases clearly demanding a "legal obligation to support," see Benjamin B. Cox, 10 T.C. 955, 959, 960 (1948), aff'd, 176 F.2d 226 (3d Cir. 1949); Commissioner v. Murray, 174 F.2d 816, 818 (2d Cir. 1949).

18. 3 Vernier, American Fanily Laws 108 et seq. (1931). And a pre-divorce agreement meets the statutory requirement even where a divorce decree specifying no alimony has terminated the husband's obligation to support. Tuckie G. Hesse, 7 T.C. 700 (1946).

19. When the decree provides no alimony, the divorce court generally cannot later revive the husband's support obligation by modifying the decree to impose alimony. Sce 2 Vernier, AMERICAN FaMily Laws 265 (1931).

20. Ibid.

21. 183 F.2d 803 (D.C. Cir. 1950).

22. Actually the court was not so specific in its holding, merely citing a combination of four facts as rendering the payments non-taxable to the wife: non-incorporation of original agreement; execution of revision after divorce decree; lack of continuing court supervision; and express termination of original agreement by revision. Since the first three factors are all relevant to the non-existence of a legal obligation to support, however, the decision seems to rest on this ground. Ibid. 
Murray, ${ }^{23}$ where the original agreement had been incorporated in the divorce decree but the parties had failed to obtain a new decree embodying their revision, the court found that the only existing legal obligation to support stemmed from the original decree. The court taxed the wife for payments under the revision because they were within the limit of the original settlement. ${ }^{24}$ But the court suggested that if the revision had increased payments, the increment would have been barred as exceeding the existing legal obligation. $^{25}$ Only if the original agreement were embodied in the divorce decree and the parties secured a modifying decree incorporating a revision would the wife be taxed on increased payments. ${ }^{20}$

This approach produced unwarranted discrimination among revisions designed to meet changed financial circumstances. By procuring a modifying decree, the parties could revise either alimony or payments made under an original agreement incorporated in a decree without shifting the tax burden. However, where the parties attempted a similar revision but failed or were unable to secure a modifying decree, the husband incurred the risk of bearing the tax burden on any increase or of losing his deduction for the full amount of post-revision payments.

A recent decision by the First Circuit, Smith v. Commissioncr, 27 suggests an end to this discrimination by a broadened interpretation of "legal obligation." In the Smith case the divorce decree incorporated an agreement. 29 And by a later agreement the parties revised payments and expressly terminated the original. Although they secured a new court decree ending the obligation imposed by the decree of divorce, they failed to have the revision included in the modifying decree. ${ }^{29}$ Thus technically there was no "legal obligation to support" at the time of the revision. ${ }^{30}$ Yet the court affirmed the Tax Court's holding that the revised payments were taxable to the wife under Section $22(\mathrm{k}) .^{31}$ The implication of the decision is clear: any revision

23. 174 F.2d 816 (2d Cir. 1949).

24. Ibid.

25. Id. at 818.

26. Ibid. See also Gale v. Commissioner, 191 F.2d 79 (2d Cir. 1951) (inereased alimony under madifying decree taxed to wife).

27. 192 F.2d 841 (1st Cir. 1951).

28. Id. at 842 .

29. Incorporation of an agreement in a modifying decree would give the divoree court continuing power of supervision over the parties. But since the First Circuit aecepted the petitioner's view that following the revision there was only a contractual obligation, it apparently recognized that the divorce court had not incorporated the revision and no longer had such power. Ibid.

30. See p. 1200 supra.

31. Smith v. Commissioner, 192 F.2d 841 (1st Cir. 1951). For the Tax Court opinion, see Dorothy Briggs Smith, 16 T.C. 639 (1951). 
will satisfy the "legal obligation" requirement if the original agreement was executed while a legal obligation to support existed. ${ }^{\mathbf{3 2}}$

Assuming that the "legal obligation" requirement is met, an agreement must also qualify as "incident to" divorce in order to be taxed to the wife under $22(\mathrm{k}) .^{33}$ Courts generally have found such "incidence" only where the agreement is executed "prior [to] or coincident [with]" the decree. ${ }^{34} \mathrm{By}$ definition, an agreement incorporated in the decree satisfies this requirement whereas one originally conceived after the decree just as clearly fails to mect it. But where agreements made prior to divorce were revised after the decree and such revision was not incorporated in a modifying decree, early opinions denied Section 22(k) tax treatment. ${ }^{35}$ Since not made "prior to or coincident with" the divorce decree, revisionary agreements were held not "incident to" the divorce. ${ }^{36}$

Recent cases apparently have liberalized the "prior to" test of "incidence." Although foreshadowed by a 1950 opinion of the Court of Claims, ${ }^{37}$ the First Circuit's Smith opinion sets forth most clearly the new approach. In effect, revisionary agreements are given the same status as the original. So long as the original agreement can qualify as "prior to or coincident with" the divorce, the revision can also qualify. ${ }^{38}$

- But even where an agreement had been executed "prior to" the decree, it had to pass a further obstacle before it could be held "incident to" the divorce:

32. The First Circuit remarked that "[t]he genesis of the [original] and [revisionary] agreements was the same-a satisfaction by the husband of his marital obligation ...," and that "[t]he origin or motive for the [revisionary] agreement can be traced to no obligation other than one arising from a ... marital relationship." Smith v. Commissioner, 192 F.2d 841 (1st Cir. 1951).

33. INT. REv. CODE $\S 22(\mathrm{k})$.

34. Benjamin B. Cox, 10 T.C. 955, 958 (1948), aff'd, 176 F.2d 226 (3d Cir. 1949). Cf. Commissioner v. Walsh, 183 F.2d 803 (D.C. Cir. 1950).

35. Commissioner v. Walsh, 183 F.2d 803 (D.C. Cir. 1950) ; Commissioner v. Murray, 174 F.2d 816 (2d Cir. 1949).

36. Natalia D. Murray, 7 T.C.M. 365 (1948), aff'd, 174 F.2d 816 (2d Cir. 1949). Cf. Commissioner v. Walsh, 183 F.2d 803 (D.C. Cir. 1950).

37. Mahana v. United States, 88 F. Supp. 285 (Ct. Cl.), cert. denied, 339 U.S. 978 (1950). See also Helen Scott Fairbanks, 15 T.C. 62 (1950).

38. "[S] ince the [original] agreement was incident to the divorce decree, . . . the [revisionary] agreement was also incident thereto." Smith v. Commissioner, 192 F.2d 841, 844 (1st Cir. 1951).

The court refused to be influenced by the fact that the revision expressly terminated and cancelled the original agreement. Previously, agreements containing such termination provisions had been treated as new agreements. See Walsh v. Commissioner, 183 F.2d 803 (D.C. Cir. 1950) ; Commissioner v. Murray, 174 F.2d 816 (2d Cir. 1949). The Smith view is more realistic. A revision performs the same function as its original, and termination or cancellation provisions merely reflect the husband's desire not to become liable for payments under both instruments at the same time. 
the parties must have mutually contemplated divorce when they executed it. 09 Although nothing in the statute suggests this requirement, a questionable reading of the Senate report accompanying the $19 \$ 2$ Act apparently led courts to this conclusion. ${ }^{20}$

The contemplation requirement has proved unsatisfactory. In view of the Congressional purpose to tax to the wife all payments "in lieu of alimony," "11 only the function of the payment seems relevant. But agreements initially intended only to cover informal separation were excluded by the contemplation requirement even though they were later used by the divorce court in lieu of prescribing alimony. ${ }^{42}$ Moreover, even where the parties actually had contemplated divorce, they faced a difficult problem of proof. What would probably constitute the best evidence of an intent to divorce-the inclusion of a statement to such effect in the agreement-was often omitted for fear of a collusion charge which might void the agreement or bar the divorce. ${ }^{\text {i3 }}$ So taxpayers often needed circumstantial evidence ${ }^{\text {is }}$ to prove a mutual state of

39. See, e.g., Robert Wood Johnson, 10 T.C. 647 (1948). The parties were required to have intended divorce or legal separation and to have draited the agreement for that reason. The fact that they contemplated a different decree than the one finally entered did not mean that the agreement was not "incident." Jessie L. Fry, 13 T.C. 658, 661 (1949); George T. Brady, 10 T.C. 1192, 1198 (1948). But there had to be more than the mere recognition of the "... possibility of divorce at some unspecified time" Joseph L. Ierner, 15 T.C. 379, 386 (1950), rev'd, 195 F.2d 296 (2d Cir. 1952).

At first both parties had to mutually contemplate divorce. Robert Wood Johnson, supra. But the Second Circuit later decided that only one party need contemplate it. Izrastzoff v. Commissioner, 193 F.2d 625 (2d Cir. 1952), rezersixg Estate of Daniel G. Reid, 15 T.C. 573 (1950).

40. The relevant language reads: "This section [22(k)] does not apply to that part of any periodic payment attributable to any interest in the property so transferred, which interest originally belonged to the wife, unless she received it from her husband in contemplation of or as ain incident to the divorce or separation vithout ... adequate consideration. ... other than the release of the husband or his property from marital obligations." Sen. RFp. No. 1631, 77th Cong., 2d Sess. S4 (1942). (Emphasis added). The purpose of this section was highly restrictive-to prevent taxing the vife under $\S 22(\mathrm{k})$ for income from her joint interest in property which she had not acquired as part of the marital settlement. U.S. Treas. Reg. 111, $\$ 29.22(k)-1$ (b) (1948).

41. Section $22(\mathrm{k})$ was added to provide ". . a new income tax treatment for payments in the nature of or in lieu of alimony or an allowance for support." H.R. ReP. No. 2333, 77th Cong., $2 d$ Sess. 71 (1942).

42. Cecil A. Miller, 16 T.C. 1010 (1951) ; Joseph C. Brightbill, S T.C.M. 112, aff'd, 178 F.2d 404 (3d Cir. 1949).

43. See, e.g., Robert Wood Johnson, 10 T.C. 647, 653 (1948); Bertram G. Zilmer, 16 T.C. 365,366 (1951); George T. Brady, 10 T.C. 1192, 1197, 1198 (1948).

Actually, such a fear is based on questionable interpretation of the case law. The general rule is that a bona fide settlement regarding alimony, although it contemplates divorce, is not collusive if it does not induce procurement of the divorce. McCauley v. MeCauley, 88 N.J. Eq. 392, 103 Atl. 20 (1918); Allen v. Allen, 111 Fla. 733, 150 Sv. 237 (1933).

44. The courts have used the following facts, either singly or in combination with each other: letters written during negotiation, Robert Wood Johnson, 10 T.C. 647 (1948), 
mind which had existed many years before. ${ }^{45}$ And although few courts actually failed to find the requisite contemplation, ${ }^{46}$ the factual nature of the problem begot constant litigation. $\mathbf{4 7}$

Recently, however, in Lerner $v$. Commissioner, ${ }^{48}$ the Second Circuit rejected the contemplation test. ${ }^{40} \mathrm{~A}$ pre-divorce agreement called for annual payments to the wife during her lifetime. The decree neither incorporated the agreement nor provided alimony. ${ }^{60}$ And, in addition, there was insufficient evidence that the parties had contemplated divorce. ${ }^{51}$ The Tax Court had refused to allow the husband the Section $23(\mathrm{u})$ deduction on the ground that divorce had not been mutually contemplated.52 But, in reversing, the Second Circuit declared that payments pursuant to an agreement would replace alimony-and comply with Congresional intent-if, first, the agreement survived divorce ${ }^{53}$ and, second, the divorce court had used the payments to replace alimony. 54 The court did not say whether both findings are necessary for Section $22(k)$ tax treatment.5

George T. Brady, 10 T.C. 1192 (1948); discussions between the parties, Robert Wood Johnson, supra, Floyd W. Jefferson, 13 T.C. 1092 (1949), Charles Campbell, 15 T.C. 355 (1950); wording of the agreement, George T. Brady, stipra; short period elapsed between execution of agreement and procurement of divorce, Tuckie G. Hessc, 7 T.C. 700 (1946) ; same attorney represented party in negotiation of agreement and in divorce proceedings, ibid.

45. See, e.g., Izrastzoff v. Commissioner, 193 F.2d 625 (2d Cir. 1952) (31 years); Robert Wood Johnson, 10 T.C. 647 (1948) (19 years); Tuckie G. Hesse, 7 T.C. 700 (1946) (12 years).

46. Only three reported cases fell. Cecil A. Miller, 16 T.C. 1010 (1951); Joseph C. Brightbill, 8 T.C.M. 112, aff'd, 178 F.2d 404 (3d Cir. 1949); Estate of Daniel G. Reid, 15 T.C. 573 (1950), rev'd sub nom., Izrastzoff v. Commissioner, 193 F.2d 625 (2d Cir. 1952).

47. Approximately thirty reported cases were decided under the contemplation theory.

48. 195 F.2d 296 (2d Cir. 1952).

49. "[Payments] should not be be denied effect under the statute merely because there is no evidence that divorce and settlement were contemporaneously planncd and carried out." Id. at 298.

50. Id. at 297 .

51. Id. at 298.

52. Joseph L. Lerner, 15 T.C. 379 (1950).

53. Lerner v. Commissioner, 195 F.2d 296, 299 (2d Cir. 1952).

54. Ibid. Had the court desired to keep the "contemplation" test, it might have based its decision on Izrastzoff v. Commissioner, 193 F.2d 625 (2d Cir. 1952). This opinion, which had come down after the Tax Court opinion in the Lerner case, had already broadened the contemplation requirement by holding that contemplation by one party, not mutual contemplation, was all that was required. Although there was some evidence that one party had contemplated divorce in the Lerner case and the petitioner's counsol argued the Izrastzoff rationale, see Reply Brief for Petitioner, the court apparently felt that even this approach was unduly narrow and troublesome. Lerner v. Commissioner, 195 F.2d 296, 298, 299 (2d Cir. 1952).

55. Ibid. 
Acceptance by other courts of the Smith and Lerner approach should effect a desirable expansion of the "incidence" requirement of Section $22(k) .00$ Smith will tax to the wife payments made under any post-divorce revision if the agreement which is revised was "incident to" divorce. And Lerner will make any pre-divorce agreement "incident" without regard to the original intent of the parties if payments under the agreement replace alimony.

56. The Third Circuit has already expressed its approval of Lenier and held an agreement "incident" under the Lemer rationale. Feinberg v. Commissioner, 4 P-H 1952 FED. TAX SERV. I 72,573 (3d Cir. 1952), reversing 16 T.C. 1485 (1951).

The Tax Court, however, recently held an agreement not "incident" on facts which indicate that the decision is contrary to both Lemer and Feisberg. Florence B. Moses, 18 T.C. No. 128 (1952). The court made an unconvincing attempt to distinguish the almost identical Feinberg case and distinguished Lemer on the ground that there the divorce court had "adopted" the agreement "in the divorce proceedings." Ibid. In Lemer, it is true, the divorce referee referred to the agreement. Lerner v. Commissioner, 195 F.2d 296, 297 (2d Cir. 1952). But the Second Circuit's rationale was much broader. It relied not on adoption by the divorce court but on "the fact that the substance of the decree was geared to [the agreement's] continuing in force in lieu of prescribed alimony. ..." Id. at 299. Thus Lomer would seem to apply to any case in which no alimony is awarded. It is clear from language in the lloses opinion that the Tax Court is reluctant to abandon the contemplation test. But in view of the Lemer and Feinberg opinions, there is a strong possibility that the decision will be appealed and reversed. 